\title{
Using Taguchi Method to Optimize Welding Pool of Dissimilar Laser Welded Components
}

\author{
E. M. Anawa and A. G. Olabi and \\ School of Mechanical \& Manufacturing Eng., Dublin City University, Dublin 9, Ireland \\ ezzeddin.hassan2@mail.dcu.ie, abdul.olabi@dcu.ie
}

\begin{abstract}
In the present work $\mathrm{CO}_{2}$ continuous laser welding process was successfully applied and optimized for joining a dissimilar AISI 316 stainless steel and AISI 1009 low carbon steel plates. Laser power, welding speed, and defocusing distance combinations were carefully selected with the objective of producing welded joint with complete penetration, minimum fusion zone size and acceptable welding profile. Fusion zone area and shape of dissimilar austenitic stainless steel with ferritic low carbon steel were evaluated as a function of the selected laser welding parameters. Taguchi approach was used as statistical design of experiment (DOE) technique for optimizing the selected welding parameters in terms of minimizing the fusion zone. Mathematical models were developed to describe the influence of the selected parameters on the fusion zone area and shape, to predict its value within the limits of the variables being studied. The result indicates that the developed models can predict the responses satisfactorily.
\end{abstract}

Keywords: Dissimilar material, Welding fusion zone, $\mathrm{CO}_{2}$ continuous laser welding, Taguchi approach.

\section{INTRODUCTION}

The demand for producing joints of dissimilar materials is continuously increasing due to their advantages, which can provide appropriate mechanical properties and good cost reduction. There are many issues/problems associated with the joining of dissimilar materials, depending on the materials being joined and process employed. In the welding of dissimilar materials different factors should be considered such as; (a) carbon migration 
from the higher carbon containing alloy to the relatively lower carbon alloy steels, especially those which are highly alloyed, (b) the differences in thermal expansion coefficients, resulting in differences in thermal residual stresses across the different weldment regions, (c) difficulty in executing the post weld heat treatment, especially in combinations wherein either of the materials being joined is susceptible to undesirable precipitation at elevated temperatures and (d) electrochemical property variations in the weldment, resulting in environmentally assisted problems [1]. Dissimilar welding of austenitic stainless steel with ferritic low carbon steel (A/F) is faced with the coarse grains phenomena in the weld zone and heat affected zone of fusion welds leading to low toughness and ductility due to the absence of phase transformation [2]. Laser welding has become an important industrial process because of its advantages as a bonding process over the other widely used joining techniques. Laser welding is characterized by parallelsided fusion zone, narrow weld width and high penetration. These advantages come from its high power density, which make the laser welding one of the keyhole welding processes $[3,4]$. Welding quality is strongly characterized by the weld bead geometry. Due to that the weld bead geometry plays an important role in determining the mechanical properties of the welded joints. Therefore, it is very essential the selection of the welding process parameters for obtaining optimal weld bead geometry. [5-7]. Design of Experiment (DOE) and statistical techniques are widely used to optimize process parameters. Many researches were conducted to identify the optimal process input parameters. The most important input laser welding parameters which would control the welding quality outputs are laser power, welding speed and focus position [8-12]. Taguchi method is one of the optimization techniques which could be applied to optimize input welding parameters. Optimization of process parameters is the key step in the Taguchi method in achieving high quality without increasing the cost. This is because optimization of process parameters can improve performance characteristics. The optimal process parameters obtained from the Taguchi method are insensitive to the variation of environmental conditions and other noise factors [10]. Basically, classical process parameter design is complex and not easy to use. This is particularly true when the number of the process parameters increases, leading to a large number of experiments have to be carried out. To solve this task, Taguchi method with a special design of orthogonal arrays can be used to study the entire process parameter space with a small number of experiments only [14]. 
The obtained results from Taguchi method are insensitive to the variation of environmental conditions and other noise factors. The optimal combination of the process parameters can then be predicted [15].

This work is concerned with evaluating the effects of welding parameters on the total weld pool fusion area as a welding output and considered as a response ' $\mathrm{A}$ ' of $\mathrm{A} / \mathrm{F}$ joints and the prediction of the optimal combinations of the welding parameters with an objective of minimizing it. Welding widths at the specimen surface and at the middle depth also were studied as responses ' $\mathrm{W} 1$ ' and 'W2' respectively to detect the effect of the selected welding parameters on the welding pool shape. The welding parameters and the listed responses will be considered as inputs and outputs respectively for Taguchi analysis. Fig. 1 shows the positions of responses on the specimen.

\section{EXPERIMENTAL DESIGN AND PROCEDURE}

Taguchi approach was used for designing the experiments, L-25 orthogonal array was applied which composed of 3 columns and 25 rows, which mean that 25 experiments were carried out. Design of experiment was selected based on a three welding parameters with five levels each. The selected welding parameters for this study are: welding power, welding speed and focus point position. Table 1 show the laser input variables and experiment design levels. The Taguchi method was applied to the experimental data using statistical softwares "Design-expert 7" and "MINITAB 13". The S/N ratio for each level of process parameters is computed based on the $\mathrm{S} / \mathrm{N}$ analysis. Regardless of the category of the quality characteristic, a lower $\mathrm{S} / \mathrm{N}$ ratio corresponds to a better quality characteristic. Therefore, the optimal level of the process parameters is the level with the lowest $\mathrm{S} / \mathrm{N}$ ratio. Furthermore, a statistical analysis of variance (ANOVA) is performed for each response individually to see which process parameters are statistically significant. The optimal combination of the process parameters can then be predicted.

The materials employed in this investigation were plates of AISI 316 stainless steel and AISI 1009 milled carbon steel in dimensions of $160 \mathrm{~mm}$ x $80 \mathrm{~mm}$ x $2 \mathrm{~mm}$ each were used as work-pieces materials. The typical chemical compositions of the received materials are shown in Table 2. The joints were produced using CO2 LBW (laser beam welding) at a 
maximum laser power of $1.5 \mathrm{~kW}$ with welding conditions as described in Table 1 . Specimens for the metallographic examinations were prepared by polishing successively in 120, 240, 500 and 800emery grits, followed by a final disc polishing using 9, 6 and $3 \mu \mathrm{m}$ diamond slurry. The carbon steel side of the weldment was etched in $4 \% \mathrm{Nital}$, and the rest of the regions of the weldment were etched in a solution containing $20 \mathrm{ml}$ hydrochloric acid, $1.0 \mathrm{~g}$ sodium meta bisulphate and $100 \mathrm{ml}$ distilled water. Also, an electrolytic etching in $10 \%$ (w/o) oxalic acid was employed to reveal the features of weld metal and the evolved interfaces. The average of at least three results of welding pool area was measured for each sample. Fig. 2, Shows the effect of the welding parameters on the responses (A, $\mathrm{W} 1, \mathrm{~W} 2$ ) of some of selected experiments listed in Table 3, and the variation on weld bead geometry. The experimental measured responses are presented in Table 3.

\section{RESULTS AND DISCUSSION}

The area of the fusion welding zone (A) was measured by using the transverse sectioned specimens, the optical microscope and image analyser software. Using the same procedure the welding pool width at surface (W1) and the welding pool width at the middle depth (W2) of the specimens also were measured and analysed as process responses. The measured responses are listed in Table 3 and exhibited in Fig. 1. Design expert 7 software had been used for analysing the measured responses. The fit summary output indicates that the models developed are statistically significant for the prediction of the responses therefore they will be used for further analysis. It has been seen that the welding pool and penetration are controlled by the rate of heat input, which is a function of laser power and welding speed [16]. But the focusing parameter is mostly affecting the weld pool surface width.

\subsection{Orthogonal Array Experiment}

In the present study, the interaction between the welding parameters is neglected. Therefore, degrees of freedom owing to the three sets of five-level welding process parameters were analysed. The degrees of freedom for the orthogonal array should be greater than or at least equal to those for the process parameters. In this study, an L25 orthogonal array with three columns and 25 rows was used. This array has twelve degrees of freedom and it can handle five-level process parameters. Twenty-five experiments were 
required to study the welding parameters using L25 orthogonal array. The experimental layout for the welding process parameters using the L25 orthogonal array is shown in Table 3 and the responses for signal-to-noise ratio $\mathrm{S} / \mathrm{N}$ are presented in Table 4.

\subsection{The Signal-to-Noise (S/N) Ratio Analysis}

In order to evaluate the influence of each selected factor on the responses: The signal-to-noise ratios $\mathrm{S} / \mathrm{N}$ for each control factor had to be calculated. The signals have indicated that the effect on the average responses and the noises were measured by the influence on the deviations from the average responses, which would indicate the sensitiveness of the experiment output to the noise factors. The appropriate $\mathrm{S} / \mathrm{N}$ ratio must be chosen using previous knowledge, expertise, and understanding of the process. When the target is fixed and there is a trivial or absent signal factor (static design), it is possible to choose the $\mathrm{S} / \mathrm{N}$ ratio depending on the goal of the design. In this study, the $\mathrm{S} / \mathrm{N}$ ratio was chosen according to the criterion the-smaller-the-better, in order to minimize the responses. The $\mathrm{S} / \mathrm{N}$ ratio for the-smaller-the-better target for all the responses was calculated as follows:

\section{$S / N=-10 \log _{10}\left[\sum y^{2} / n\right]$}

Where: $\mathrm{y}$ is the average measured fusion area, $\mathrm{n}$ the repetitions, in this study $=25$

Using the above-presented data with the selected above formula for calculating $\mathrm{S} / \mathrm{N}$, the Taguchi experiment results are summarised in Table 4 and presented in Fig. 3, which were obtained by means of MINITAB 13 statistical software. It can be noticed from this Fig. that the $\mathrm{S} / \mathrm{N}$ plot, that the travel speed ' $\mathrm{S}$ ' is the most important factor affecting the responses; the minimum value of response is at the highest level of ' $\mathrm{S}$ '. Laser power has a lower relevant effect. While the focus point position plots show the lowest effect among those factors. Main effects plot for S/N ratios suggest that those levels of variables would minimise the weld pool dimensions, also were robust against variability due to noises as presented in Fig. 3. 


\subsection{Analysis of Variance}

The purpose of the analysis of variance (ANOVA) is to investigate which welding process parameters significantly affect the quality characteristic. This is accomplished by separating the total variability of the $\mathrm{S} / \mathrm{N}$ ratios, which is measured by the sum of the squared deviations from the total mean of the $\mathrm{S} / \mathrm{N}$ ratio, into contributions by each welding process parameter and the error $[17,18]$. The test for significance of the regression model, the test for significance on individual model coefficients and the lack-of- fit test were performed using Design Expert 7 software.

Step-wise regression method; which eliminates the insignificant model terms automatically was applied and exhibited in ANOVA Tables 5-7 for the reduced quadratic model. ANOVA Tables summarise the analysis of three variances of the responses and show the significant models.

\subsubsection{ANOVA Outputs}

F Value: Test for comparing model variance with residual (error) variance. When the variances are close to each other, the ratio will be close to one and it is less likely that any of the factors have a significant effect on the response. F Value is calculated by term mean square divided by residual mean square. Prob > F: Probability of seeing the observed $\mathrm{F}$ value if the null hypothesis is true (there is no factor effect). If the Prob>F value is very small (less than 0.05) then the individual terms in the model have a significant effect on the response. Precision of a parameter estimate is based on of the number of independent samples of information which can be determined by degree of freedom (df). The degree of freedom equals to the number of experiments minus the number of additional parameters estimated for that calculation. The same tables show also the other adequacy measures $R^{2}$, adjusted $R^{2}$, adequacy precision $\mathrm{R}^{2}$ and predicted $R^{2}$ for each response. The entire adequacy measures were close to 1 , which are reasonable and indicate adequate models. The adequate precision compares the range of the predicted value at the design points to the average predicted error. In this study the value of adequate precision are significantly greater than 4 . The adequate precision ratio above 4 indicates adequate model discrimination.

The analysis of variance indicates that for the welding pool area (A) model, the main effect was the welding speed (S), the second order effect was the laser power (P) and the two level interaction of laser welding and welding speed ( $\mathrm{P}$ and $\mathrm{S}$ ) are the most 
significant model parameters. Secondly for the welding pool width at the work piece surface (W1) model, the analysis indicated that there is a linear relationship between the main effects of the three parameters. Also, in case of welded pool width at the middle of work piece (W2) model the main effect of laser power (P), welding speed (S), focused position $(F)$, the second order effect of welding speed $\left(\mathrm{S}^{2}\right)$ are significant model terms. However, the main effect of welding speed (S) is the most important factor influent the welding pool.

The final mathematical models in terms of actual factors as determined by design expert software are shown below.

\subsubsection{Final Equations in Terms of Actual Factors:}

$$
\begin{aligned}
& A=-3.681+6.084 * P+6.479 E-003 * S-7.028 E-003 * P * S \\
& W 1=+5.757-1.922 * P-1.878 E-003 * S+3.260 * F-2.955 * P * F \\
& W 2 \quad=+2.010+0.218 * P-3.696 E-003 * S-0.152 * F+2.006 E-006 * S^{2}(3)
\end{aligned}
$$

\subsection{Model Validation}

The final step is to predict and verify the improvement of the response using the optimal level of the welding process parameters.

Figs. 4-6 show the relationship between the actual and predicted values of A, W1, and $\mathrm{W} 2$, respectively. These figures indicate that the developed models are adequate because the residuals in prediction of each response are negligible, since the residuals tend to be close to the diagonal line. Furthermore, to verify the satisfactoriness of the developed models, three confirmation experiments were carried out using new test conditions at optimal parameters conditions, obtained using the design expert software. Table 8 expresses the best ten parameters combination which were predicted using software. First value indicates the lowest responses and so on. The A, W1 and W2 of the validation experiments were selected from Table 8. Table 9 summarizes the experiments conditions, the actual experimental values, the predicted values and the percentages of error. It could be concluded that the models developed could predict the responses with a very small error. A, W1 and W2 were greatly improved through this optimization. 


\section{EFFECT OF THE PARAMETERS ON RESPONSES}

The reason for predicting the welding pool geometry is to develop a model which would include the optimizations step for future work. Fig. 7 contour graph shows the effect of $\mathrm{S}$ and $\mathrm{P}$ on the total welding pool area (A) at $\mathrm{F}=-0.5 \mathrm{~mm}$. Fig. 8 contour graph shows the effect of $\mathrm{P}$ and $\mathrm{F}$ on the welding pool width at the work piece surface (W1) at $\mathrm{S}=750$ $\mathrm{mm} / \mathrm{min}$. Fig. 9 contour graph shows the effect of $\mathrm{P}$ and $\mathrm{S}$ on the welding pool width at the middle of work piece (W2) at $\mathrm{F}=-0.5$.

\subsection{Welding Pool Area 'A'}

In the present study the fusion area (welding pool) 'A' of dissimilar joints between stainless steel and low carbon steel was measured and plotted in 3D graph as presented in Fig. 10. This Fig. shows that the welding speed has the most significant effect on the process. The increase in welding speed ' $S$ ' rate, lead to the reduction of the fusion area of the welding pool. When welding speed equal maxima at $1000 \mathrm{~mm} / \mathrm{min}$, as presented in Table 3, the fusion area is minima and equals $1.598 \mathrm{~mm}^{2}$ which present the best achieved results. It is also noted that changes in the laser power ' $\mathrm{P}$ ' rate would lead to change the fusion area value. By increasing laser power the fusion area tends to decrease up to lower value at laser power equals $1.15 \mathrm{~kW}$ then start to trend-on up to laser power equal to 1.33 $\mathrm{kW}$. Further increases of laser power value result in the fusion area increasing again. The fusion area has the minimum value at laser power equal $1.33 \mathrm{~kW}$ these results are shown in Fig. 2 and 3. From Fig. 3 it's clear that the focusing position ' $F$ ' has insignificant effect on the welding pool, where by changing the focusing position the welding pool will not be consequentially changed and this effect is ensured in Table 4 in which the focusing position has the greater value $($ rank $=3)$ in $\mathrm{S} / \mathrm{N}$ ratio.

\subsection{Welding Pool Width at the Work Piece Surface (W1).}

The results and the model obtained for the response indicate that the $\mathrm{S}$ and $\mathrm{F}$ are the most important factors affecting W1 value. An increase in S leads to a decrease in W1. This is due to the laser beam traveling at high speed over the welding line when $S$ is increased. Therefore the heat input decreases leading to less volume of the base metal being melted, consequently the width of the welded zone decreases. Moreover, defocused 
beam, which mean wide laser beam results in spreading the laser power onto wide area. Therefore, wide area of the base metal will be melted leading to an increase in W1 or vice versa. The result shows also that $\mathrm{P}$ contributes secondary effect in the response width dimensions. Increases in $\mathrm{P}$ will results in slight increases in $\mathrm{W} 1$, due to the increase in the power density. Fig. 11 shows 3D plots for the effect of process parameters on the W1 width.

\subsection{Welding Pool Width at the Middle of the Work Piece (W2)}

From the results it is clear that the three parameters are significantly affecting the W2 value. Using a focused beam results in an increase in the power density, which indicates that the heat will be localize in a small metal portion, resulting in an increase in the power density leading to increasing W2 value. The model shows that the response is proportioned inversely with F. The result shows that the changes in F parameter effects W1, W2 and didn't effect A. This may be interpreted that as F decreased, W1 increasing, W2 decreased and vice versa, so the total area $\mathrm{A}$ will not be effected by changing $\mathrm{F}$. The increase in $\mathrm{P}$ leads to an increase in the heat input, therefore, more molten metal and consequently wider W2 will be achieved. However, the idea is reversed in the case of S effect, because the $\mathrm{S}$ is inversely proportioned with the heat input. Fig. 12 shows 3D plots to present the effect of process parameters on the $\mathrm{W} 2$ value.

\section{CONCLUSION}

The following points can be concluded from this study:

i) Using Laser welding could produce a small welding pool and a narrow HAZ.

ii) Welding speed has the stronger effect on the fusion area size among the selected parameters; which is proportional inversely with responses.

iii) Laser power has strong effect on fusion area. By changing the $\mathrm{P}$ value the response will be changed dramatically, so the $\mathrm{P}$ value should be carefully selected. The focusing position parameter has insignificant effect on the total weld pool size.

iv) The model developed can be adequately in predicting the responses within the factors domain. 


\section{ACKNOWLEDGEMENT}

Libyan educational ministry is gratefully acknowledged for the financial support of this research. Technical support from Mr. Martin Johnson and Mr. Michael May and Dublin City University are also gratefully acknowledged.

\section{REFERENCES:}

[1] P. Bala Srinivasan, V. Muthupandi, W. Dietzel, V. Sivan, An assessment of impact strength and corrosion behavior of shielded metal arc welded dissimilar weldments between UNS 31803 and IS 2062 steels, Materials and Design 27 (2006) 182-191.

[2] V.V Satyanarayana, G. Madhusudhan Reddy, T. Mohandes, Journal of Materials Processing Technology, 160 (2005) 128-137.

[3] E. M. Anawa, A. G. Olabi and M. S. J. Hashmi, Optimization of ferritic/Austenitic laser welded components, presented at AMPT2006 Inter. Conf. July 30 to 3 Aug., 2006, Las Vegas, Nevada, USA, 2006, p. 04325.

[4] W.M. Steen, Journal of Laser Applications, October 1999 , Volume 11, Issue 5, pp. 216-219 Springer, London, 1991.

[5] Y. M. Zhang, R. Kovacevic and L. Li, "Characterization and realtime measurement of geometrical appearance of the weld pool", International Journal of Machine Tools and Manufacture, 36(7), pp. 799-816, 1996.

[6] C. E. Bull, K. A. Stacey and R. Calcraft, "On line weld monitoring using ultrasonic", Journal of Non-destructive Testing, 35(2), pp. 57- 64, 1993.

[7] Y. S. Tarng and W. H. Yang, Optimisation of the Weld Bead Geometry in Gas Tungsten Arc Welding by the Taguchi Method, J Adv Manuf Technol (1998) $14: 549-554$

[8] K. Y. Benyounis, A. G. Olabi and M. S. J. Hashmi, Estimation of mechanical properties of laser welded joints using RSM, International Manufacturing Conference (2005) 565- 571.

[9] Y. S. Tarng, S. C. Juang and C. H. Chang, The use of grey-based Taguchi methods to determine submerged arc welding process parameters in hard facing, Journal of 
Materials Processing Technology, Volume 128, Issues 1-3, 6 October 2002, Pages 16.

[10] Lung Kwang Pan, Che Chung Wang, Ying Ching Hsiao and Kye Chyn Ho, Optimization of Nd:YAG laser welding onto magnesium alloy via Taguchi analysis, Optics \& Laser Technology, Volume 37, Issue 1, February 2005, Pages 33-42.

[11] Hyoung-Keun Lee, Hyon-Soo Han, Kwang-Jae Son and Soon-Bog Hong, Optimization of Nd: YAG laser welding parameters for sealing small titanium tube ends, Materials Science and Engineering: A, Volume 415, Issues 1-2, 15 January 2006, Pages 149-155.

[12] E. M. Anawa and A. G. Olabi, Effect of laser welding conditions on toughness of dissimilar welded components, J. of Applied Mechanics and Materials, Vol. 5-6, 2006, 375-380.

[13] Y.S. Tarng, S.C. Juang, C.H. Chang, The use of grey-based Taguchi methods to determine submerged arc welding process parameters in hard facing, Journal of Materials Processing Technology 128 (2002) 1-6.

[14] D.C. Montgomery, Design and Analysis of Experiments, Wiley, Singapore, 1991.

[15] E. M. Anawa, A. G. Olabi and M. S. J. Hashmi, Application of Taguchi Method to Optimize Dissimilar Laser Welded Components, presented at 23rd International Manufacturing Conference 30th Aug. to 1st Sep., 2006, Belfast, UK, p. 241-248.

[16] A.G. Olabi , G. Casalino, K.Y. Benyounis, M.S.J. Hashmi , An ANN and Taguchi algorithms integrated approach to the optimization of CO2 laser welding, Advances in Engineering Software 37 (2006) 643-648.

[17] S.C. Juang, Y.S. Tarng, Process parameter selection for optimizing the weld pool geometry in the tungsten inert gas welding of stainless steel, Journal of Materials Processing Tec Processing Technology, 160 (2005) 128-137.

[18] K.Y. Benyounis, A.G. Olabi, M.S.J. Hashmi, Effect of laser welding parameters on the heat input and weld-bead profile, Journal of Materials Processing Technology 164-165 (2005) 978-985. 


\section{List of tables:}

1. Table 1 Process parameters and design levels used.

2. Table 2 Chemical composition of the materials (wt \%).

3. Table 3 Experimental assignments, responses, and $\mathrm{S} / \mathrm{N}$ ratio.

4. Table 4 Responses for signal-to-noise ratio $(\mathrm{S} / \mathrm{N})$.

5. Table 5 ANOVA for A response model.

6. Table 6 ANOVA for $\mathrm{W} 1$ response model.

7. Table 7 ANOVA for $\mathrm{W} 2$ response model.

8. Table 8 the best parameters combinations for greater responses.

9. Table9 Confirmation experiments and base metal responses. 


\section{List of figures:}

1. Fig. 1, Shows the responses position on the work piece.

2. Fig. 2, Shows the effect of the welding parameters on the responses (A, W1, W2), and the variation on weld bead geometry

3. Fig. 3, Effects plot for $\mathrm{S} / \mathrm{N}$ ratio of the responses.

4. Fig. 4, Shows the effect of actual welding parameters on A response against predicted.

5. Fig. 5, Shows the effect of actual welding parameters on W1 response against predicted.

6. Fig. 6, Shows the effect of actual welding parameters on W2 response against predicted.

7. Fig. 7, Contour graph shows the effect of $\mathrm{P}$ and $\mathrm{S}$ parameters on the response $\mathrm{A}$.

8. Fig. 8, Contour graph shows the effect of $\mathrm{P}$ and $\mathrm{F}$ parameters on the response W1.

9. Fig. 9, Contour graph shows the effect of $\mathrm{P}$ and $\mathrm{S}$ parameters on the response W2.

10. Fig. 10, 3D graph shows the effect of $\mathrm{P}$ and $\mathrm{S}$ on $\mathrm{A}$ response at $\mathrm{F}=-0.5 \mathrm{~mm}$.

11. Fig. 11, 3D graph shows the effect of $\mathrm{P}$ and $\mathrm{S}$ on $\mathrm{W} 1$ response at $\mathrm{F}=-1 \mathrm{~mm}$.

12. Fig. 12, 3D graph shows the effect of $\mathrm{P}$ and $\mathrm{S}$ on $\mathrm{W} 2$ response at $\mathrm{F}=-1 \mathrm{~mm}$. 
Table 1 Process parameters and design levels used

\begin{tabular}{|c|c|c|c|c|c|c|c|}
\hline Variables & Code & Unit & Level 1 & Level 2 & Level 3 & Level 4 & Level 5 \\
\hline Laser Power & $\mathrm{P}$ & $\mathrm{kW}$ & 1.05 & 114.9 & 1.24 & 1.33 & 1.43 \\
\hline Welding Speed & $\mathrm{S}$ & $\mathrm{mm} / \mathrm{min}$ & 500 & 625 & 750 & 850 & 1000 \\
\hline Focus & $\mathrm{F}$ & $\mathrm{mm}$ & -1 & -0.75 & -0.5 & -0.25 & 0 \\
\hline
\end{tabular}


Table 2 Chemical composition of the materials (wt \%)

\begin{tabular}{|c|c|c|c|c|c|c|c|c|c|c|}
\hline Material & $\mathrm{C}$ & $\mathrm{Si}$ & $\mathrm{Mn}$ & $\mathrm{P}$ & $\mathrm{S}$ & $\mathrm{Cr}$ & $\mathrm{Ni}$ & $\mathrm{Nd}$ & $\mathrm{Mo}$ & $\mathrm{Fe}$ \\
\hline $\begin{array}{c}\text { Low carbon } \\
\text { steel }\end{array}$ & 0.093 & 0.027 & .210 & 0.001 & 0.005 & .043 & 0.065 & 0.024 & 0.006 & $\mathrm{Bal}$. \\
\hline $\begin{array}{c}316 \\
\text { stainless } \\
\text { steel }\end{array}$ & 0.048 & 0.219 & 1.04 & 0.013 & 0.033 & 18.028 & 10.157 & 0.098 & 1.830 & Bal. \\
\hline
\end{tabular}


Table 3 Experimental assignments, responses, and $\mathrm{S} / \mathrm{N}$ ratio.

\begin{tabular}{|c|c|c|c|c|c|c|c|}
\hline $\begin{array}{l}\text { Exp } \\
\text { No. }\end{array}$ & $\begin{array}{c}\mathrm{P} \\
\mathrm{kW}\end{array}$ & $\begin{array}{c}\mathrm{S} \\
\mathrm{mm} / \mathrm{sec}\end{array}$ & $\begin{array}{c}\mathrm{F} \\
\mathrm{mm}\end{array}$ & $\begin{array}{c}\mathrm{A} \\
\mathrm{mm}^{2}\end{array}$ & $\begin{array}{l}\mathrm{W} 1 \\
\mathrm{~mm}\end{array}$ & $\begin{array}{l}\mathrm{W} 2 \\
\mathrm{~mm}\end{array}$ & $\mathrm{~S} / \mathrm{N}$ \\
\hline 1 & 1.05 & 500 & 0.00 & 2.427 & 2.875 & 0.972 & -7.019 \\
\hline 2 & 1.05 & 625 & -0.25 & 1.953 & 2.264 & 0.78 & -5.028 \\
\hline 3 & 1.05 & 750 & -0.50 & 2.021 & 2.349 & 0.674 & -5.657 \\
\hline 4 & 1.05 & 875 & -0.75 & 2.058 & 2.198 & 0.639 & -4.995 \\
\hline 5 & 1.05 & 1000 & -1.00 & 1.758 & 1.617 & 0.544 & -3.953 \\
\hline 6 & 1.15 & 500 & -0.25 & 2.115 & 2.358 & 1.032 & -4.588 \\
\hline 7 & 1.15 & 625 & -0.50 & 2.162 & 1.92 & 0.844 & -5.292 \\
\hline 8 & 1.15 & 750 & -0.75 & 2.190 & 2.494 & 0.663 & -5.125 \\
\hline 9 & 1.15 & 875 & -1.00 & 2.237 & 2.06 & 0.579 & -5.008 \\
\hline 10 & 1.15 & 1000 & 0.00 & 1.872 & 2.225 & 0.616 & -3.811 \\
\hline 11 & 1.24 & 500 & -0.50 & 3.641 & 3.211 & 1.103 & -9.624 \\
\hline 12 & 1.24 & 625 & -0.75 & 2.205 & 2.674 & 0.831 & -6.328 \\
\hline 13 & 1.24 & 750 & -1.00 & 1.742 & 2.034 & 0.656 & -4.346 \\
\hline 14 & 1.24 & 875 & 0.00 & 1.785 & 1.502 & 0.703 & -2.964 \\
\hline 15 & 1.24 & 1000 & -0.25 & 1.709 & 1.883 & 0.759 & -3.706 \\
\hline 16 & 1.33 & 500 & -0.75 & 3.100 & 1.856 & 1.026 & -7.235 \\
\hline 17 & 1.33 & 625 & -1.00 & 2.707 & 2.097 & 0.646 & -6.532 \\
\hline 18 & 1.33 & 750 & 0.00 & 2.328 & 2.543 & 1.045 & -6.361 \\
\hline 19 & 1.33 & 875 & -0.25 & 1.784 & 2.297 & 0.718 & -4.759 \\
\hline 20 & 1.33 & 1000 & -0.50 & 1.598 & 1.639 & 0.719 & -3.573 \\
\hline 21 & 1.43 & 500 & -1.00 & 2.877 & 2.152 & 0.953 & -7.302 \\
\hline 22 & 1.43 & 625 & 0.00 & 3.136 & 2.952 & 0.936 & -8.112 \\
\hline 23 & 1.43 & 750 & -0.25 & 2.261 & 2.416 & 0.68 & -5.802 \\
\hline 24 & 1.43 & 875 & -0.50 & 1.904 & 1.832 & 0.652 & -4.356 \\
\hline 25 & 1.43 & 1000 & -0.75 & 1.647 & 1.213 & 0.696 & -2.057 \\
\hline
\end{tabular}


Table 4 Responses for signal-to-noise ratio (S/N).

\begin{tabular}{|c|c|c|c|c|c|c|c|}
\hline levels & 1 & 2 & 3 & 4 & 5 & Delta & Rank \\
\hline $\mathrm{P}, \mathrm{kW}$ & -6.49 & -6.52 & -6.98 & -7.22 & -6.15 & 1.07 & 2 \\
\hline $\mathrm{S}, \mathrm{mm} / \mathrm{min}$ & -8.89 & -7.59 & -6.43 & -5.78 & -4.68 & 4.21 & 1 \\
\hline $\mathrm{F}, \mathrm{mm}$ & -6.91 & -6.82 & -5082 & -6074 & -7.09 & 1.27 & 3 \\
\hline
\end{tabular}


Table 5 ANOVA for the welding pool area model

\begin{tabular}{|c|c|c|c|c|c|c|}
\hline Source & $\begin{array}{l}\text { Sum of } \\
\text { Squares }\end{array}$ & df & $\begin{array}{l}\text { Mean } \\
\text { Square }\end{array}$ & $\begin{array}{c}\mathrm{F} \\
\text { Value }\end{array}$ & $\begin{array}{c}\text { p-value } \\
\text { Prob. > F }\end{array}$ & \\
\hline Model & 4.71 & 3 & 1.57 & 18.18 & $<0.0001$ & significant \\
\hline $\mathrm{P}$ & 0.34 & 1 & 0.34 & 3.99 & 0.0059 & \\
\hline S & 3.68 & 1 & 3.68 & 42.54 & $<0.0001$ & \\
\hline PS & 0.70 & 1 & 0.70 & 8.06 & 0.0089 & \\
\hline Residual & 1.81 & 21 & 0.086 & & & \\
\hline Cor. Total & 6.53 & 24 & & & & \\
\hline \multicolumn{4}{|c|}{ R-Squared $=0.7220$} & \multicolumn{3}{|c|}{ Pred. R-Squared $=0.6052$} \\
\hline \multicolumn{3}{|c|}{ Adj. R-Squared $=0.6823$} & & \multicolumn{3}{|c|}{ Adeq. Precision $=14.955$} \\
\hline
\end{tabular}


Table 6 ANOVA for the welding pool width at the serves of the spacenem 'W1' model.

\begin{tabular}{|c|c|c|c|c|c|c|}
\hline Source & $\begin{array}{l}\text { Sum of } \\
\text { Squares }\end{array}$ & df & $\begin{array}{l}\text { Mean } \\
\text { Square }\end{array}$ & $\begin{array}{c}\mathrm{F} \\
\text { Value }\end{array}$ & $\begin{array}{l}\text { p-value } \\
\text { Prob. > F }\end{array}$ & \\
\hline Model & 2.98 & 4 & 0.74 & 6.75 & 0.0013 & significant \\
\hline $\mathrm{P}$ & 0.087 & 1 & 0.087 & 0.79 & 0.3843 & \\
\hline$S$ & 2.36 & 1 & 2.36 & 21.36 & 0.0002 & \\
\hline $\mathrm{F}$ & 0.51 & 1 & 0.51 & 4.65 & 0.0434 & \\
\hline $\mathrm{P} * \mathrm{~F}$ & 0.47 & 1 & 0.47 & 4.27 & 0.0519 & \\
\hline Residual & 2.21 & 20 & 0.11 & & & \\
\hline Cor. Total & 5.18 & 24 & & & & \\
\hline \multicolumn{4}{|c|}{ R-Squared $=0.5745$} & \multicolumn{3}{|c|}{ Pred. R-Squared $=0.3637$} \\
\hline \multicolumn{3}{|c|}{ Adj. R-Squared $=0.4894$} & & \multicolumn{3}{|c|}{ Adeq. Precision $=9.724$} \\
\hline
\end{tabular}


Table 7 ANOVA for the welding pool width at the middle of the spacemen 'W2'model.

\begin{tabular}{|c|c|c|c|c|c|c|}
\hline Source & $\begin{array}{l}\text { Sum of } \\
\text { Squares }\end{array}$ & df & $\begin{array}{l}\text { Mean } \\
\text { Square }\end{array}$ & $\begin{array}{c}\mathrm{F} \\
\text { Value }\end{array}$ & $\begin{array}{l}\text { p-value } \\
\text { Prob }>\text { F }\end{array}$ & \\
\hline Model & 0.52 & 4 & 0.13 & 20.06 & $<0.0001$ & significant \\
\hline$P$ & 0.021 & 1 & 0.021 & 3.27 & 0.0858 & \\
\hline$S$ & 0.36 & 1 & 0.36 & 56.15 & $<0.0001$ & \\
\hline$F$ & 0.072 & 1 & 0.072 & 11.25 & 0.0032 & \\
\hline$S^{2}$ & 0.062 & 1 & 0.062 & 9.57 & 0.0057 & \\
\hline Residual & 0.13 & 20 & $6.43 \mathrm{E}-03$ & & & \\
\hline $\begin{array}{l}\text { Cor } \\
\text { Total }\end{array}$ & 0.64 & 24 & & & & \\
\hline \multicolumn{4}{|c|}{ R-Squared $=0.8005$} & \multicolumn{3}{|c|}{ Pred R-Squared $=.6839$} \\
\hline \multicolumn{4}{|c|}{ Adj R-Squared $=.7606$} & \multicolumn{3}{|c|}{ Adeq Precision $=13.72$} \\
\hline
\end{tabular}


Table 8 The best parameters combinations for greater respons.

\begin{tabular}{|c|c|c|c|c|c|c|c|c|}
\hline Number & Power & Speed & Focus & $\mathrm{A}$ & $\mathrm{W} 1$ & $\mathrm{~W} 2$ & Desirability & \\
\hline 1 & 1.05 & 1000 & -1 & 1.836 & 1.713 & 0.553 & 0.923 & Selected \\
\hline 2 & 1.05 & 1000 & -0.95 & 1.836 & 1.723 & 0.553 & 0.921 & \\
\hline 3 & 1.05 & 1000 & -0.9 & 1.836 & 1.732 & 0.553 & 0.920 & \\
\hline 4 & 1.05 & 998 & -1 & 1.836 & 1.719 & 0.556 & 0.920 & \\
\hline 5 & 1.05 & 1000 & -1 & 1.832 & 1.718 & 0.560 & 0.919 & \\
\hline 6 & 1.05 & 1000 & -0.78 & 1.836 & 1.754 & 0.553 & 0.917 & \\
\hline 7 & 1.05 & 1000 & -0.53 & 1.836 & 1.801 & 0.553 & 0.912 & \\
\hline 8 & 1.05 & 1000 & -0.51 & 1.836 & 1.804 & 0.553 & 0.911 & \\
\hline 9 & 1.05 & 981 & -1 & 1.852 & 1.749 & 0.549 & 0.910 & \\
\hline 10 & 1.05 & 1000 & -0.31 & 1.836 & 1.843 & 0.553 & 0.906 & \\
\hline
\end{tabular}


Table9 Confirmation experiments and base metal responses.

\begin{tabular}{|c|c|c|c|c|c|c|c|c|c|c|c|c|}
\hline \multirow{2}{*}{$\begin{array}{c}\text { Ex } \\
\text { p. } \\
\text { No }\end{array}$} & \multirow{2}{*}{$\begin{array}{c}\mathrm{P}, \\
\mathrm{KW}\end{array}$} & \multirow{2}{*}{$\begin{array}{c}\mathrm{S}, \\
\mathrm{mm} / \\
\mathrm{min}\end{array}$} & \multirow{2}{*}{$\begin{array}{c}\mathrm{F}, \\
\mathrm{mm}\end{array}$} & \multicolumn{2}{|c|}{$\begin{array}{c}\mathrm{A}, \\
\mathrm{mm}^{2}\end{array}$} & \multirow[t]{2}{*}{$\begin{array}{r}|E| \\
\%\end{array}$} & \multicolumn{2}{|c|}{$\begin{array}{l}\mathrm{W} 1, \\
\mathrm{~mm}\end{array}$} & \multirow[t]{2}{*}{$\begin{array}{c}|E| \\
\%\end{array}$} & \multicolumn{2}{|c|}{$\begin{array}{l}\mathrm{W} 2, \\
\mathrm{~mm}\end{array}$} & \multirow[t]{2}{*}{$\begin{array}{l}|E| \\
\%\end{array}$} \\
\hline & & & & Actual & Pred. & & Actual & Pred. & & Actual & Pred. & \\
\hline 1 & 1.05 & 1000 & -1 & 1.89 & 1.84 & 2.7 & 1.67 & 1.71 & 2.3 & 0.61 & 0.55 & 10.91 \\
\hline 2 & 1.05 & 1000 & -0.95 & 1.75 & 1.84 & 4.9 & 1.59 & 1.72 & 7.6 & 0.59 & 0.55 & 7.27 \\
\hline 3 & 1.05 & 1000 & -0.9 & 1.90 & 1.84 & 3.3 & 1.84 & 1.73 & 6.4 & 0.53 & 0.55 & 3.64 \\
\hline
\end{tabular}




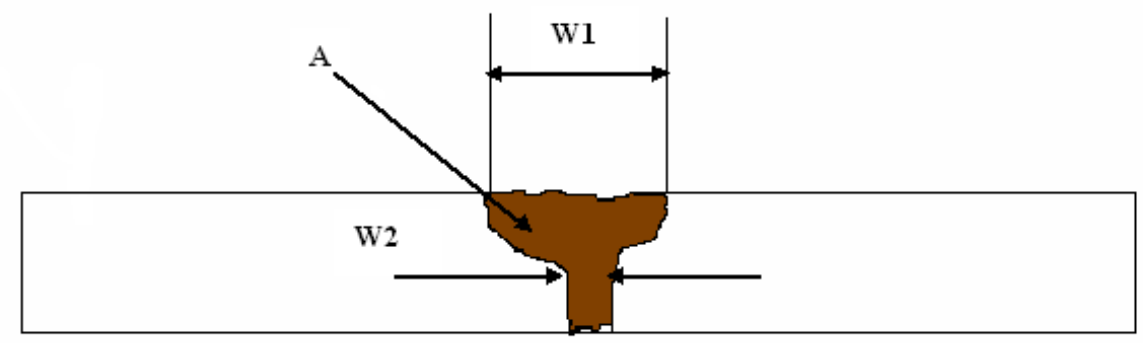

Fig. 1. shows the responses positions on the work piece. 

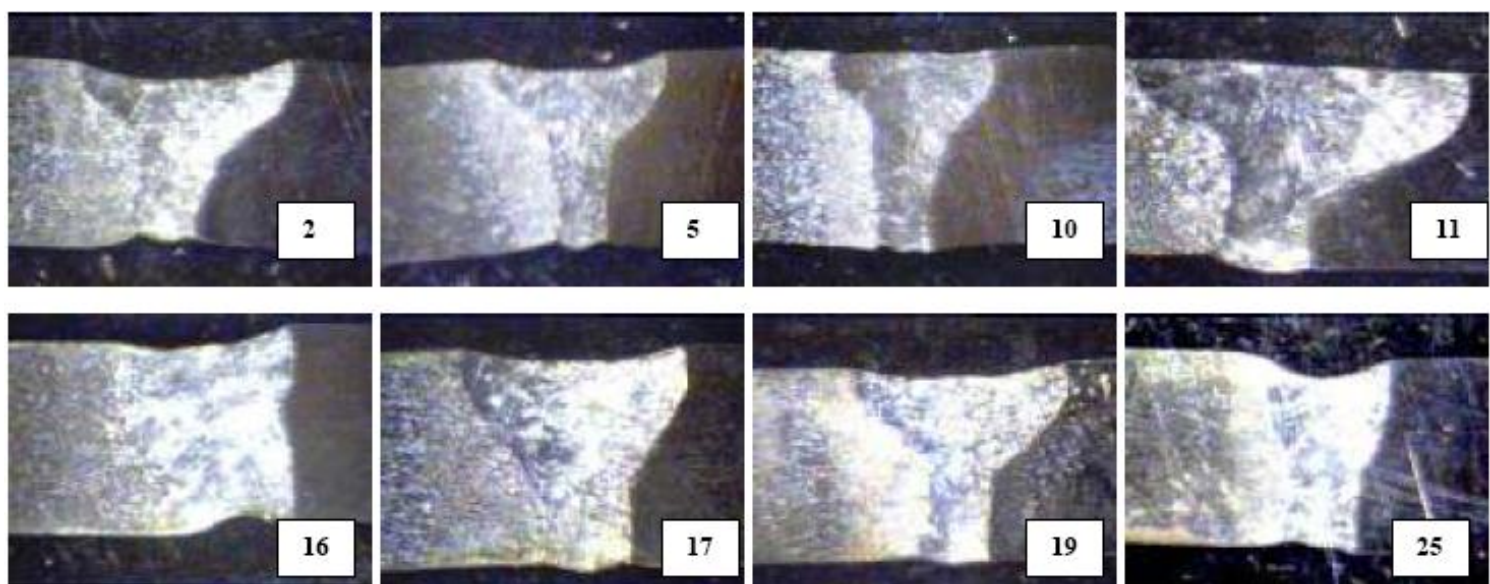

Fig. 2, Shows the effect of the welding parameters on the responses (A, W1, W2), and the variation on weld bead geometry, X10. 


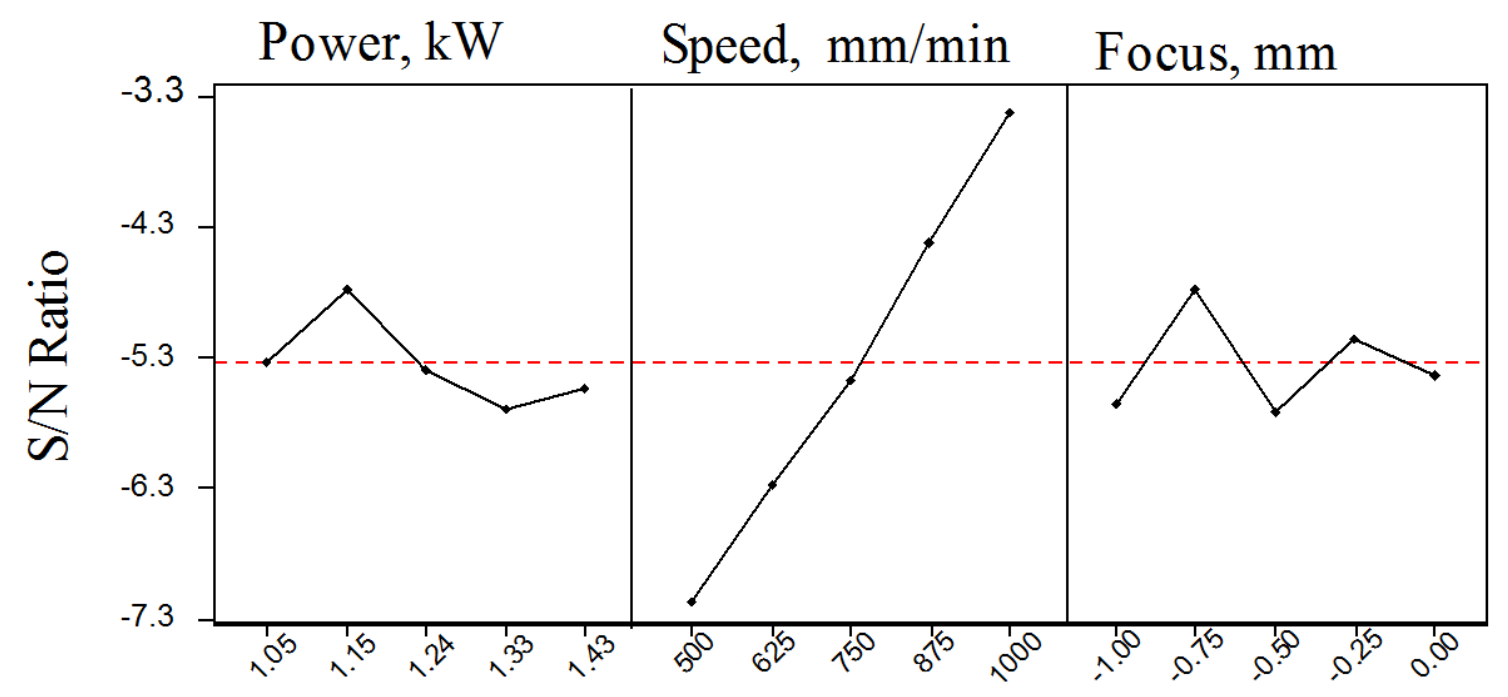

Fig. 3, Effects plot for $\mathrm{S} / \mathrm{N}$ ratio of the responses 


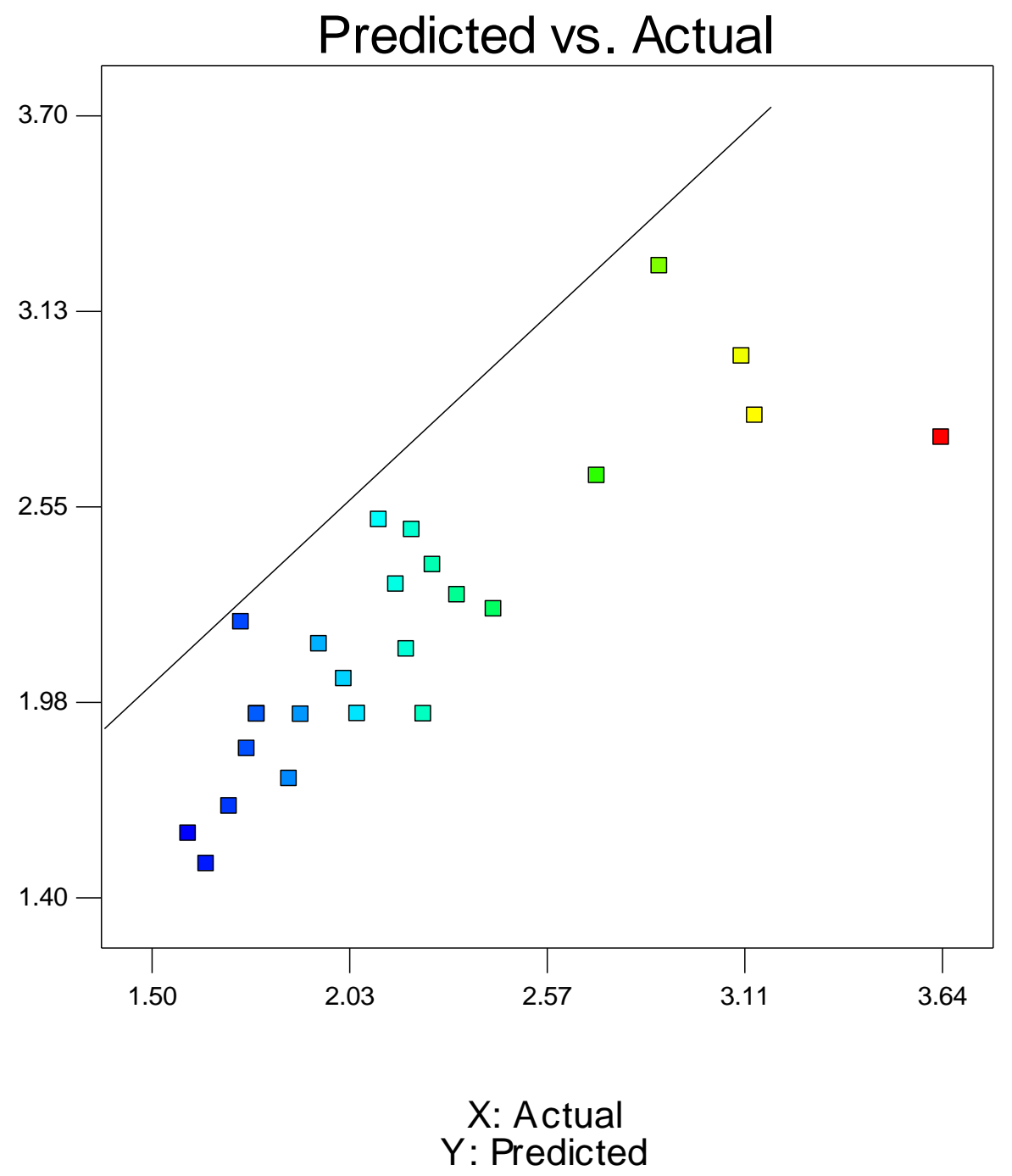

Fig. 4, Shows the effect of actual welding parameters on the welding pool area 'A' response, against predicted. 


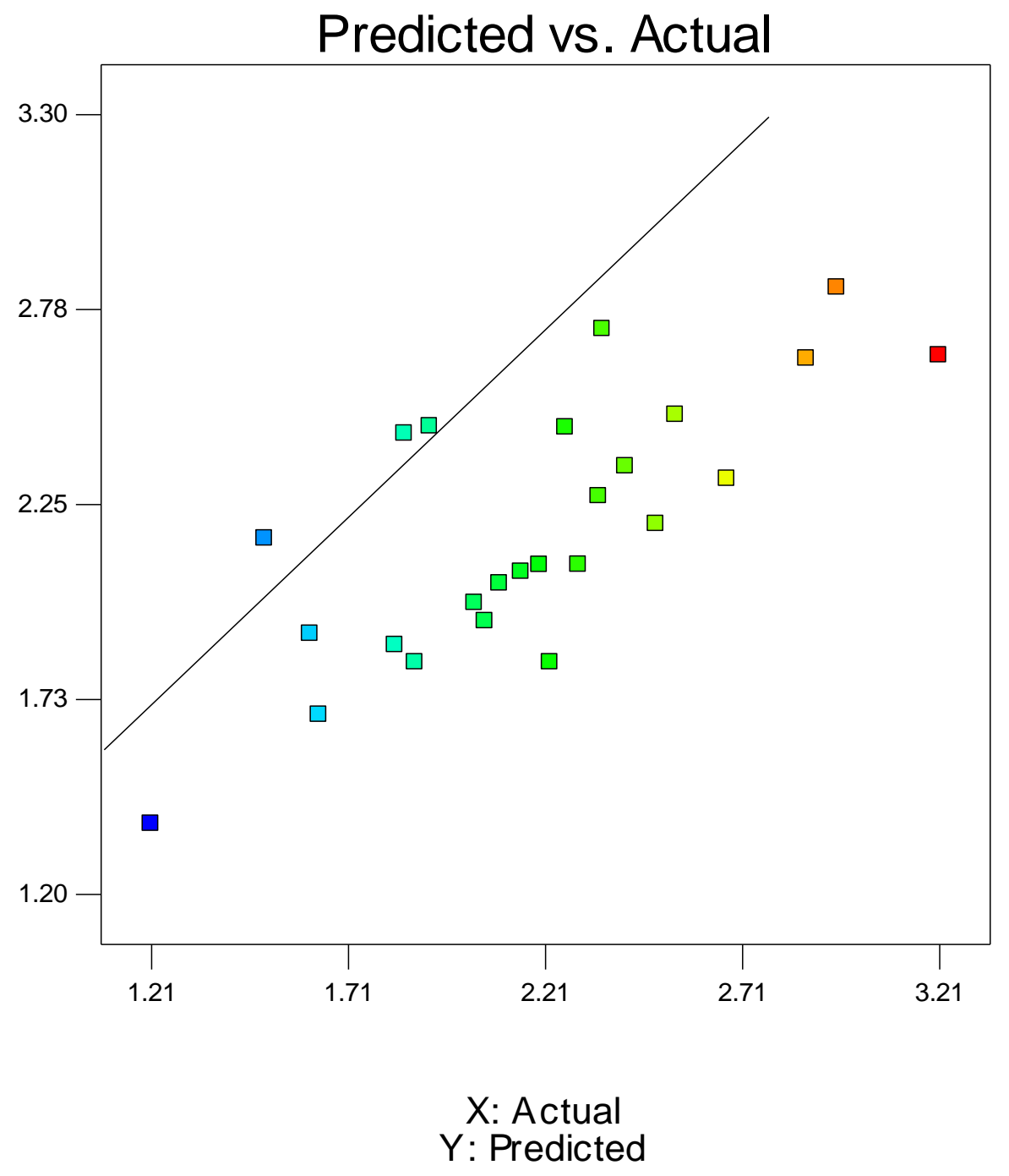

Fig. 5, Shows the effect of actual welding parameters on the welding pool width at the serves of the spacenem 'W1'response, against predicted. 


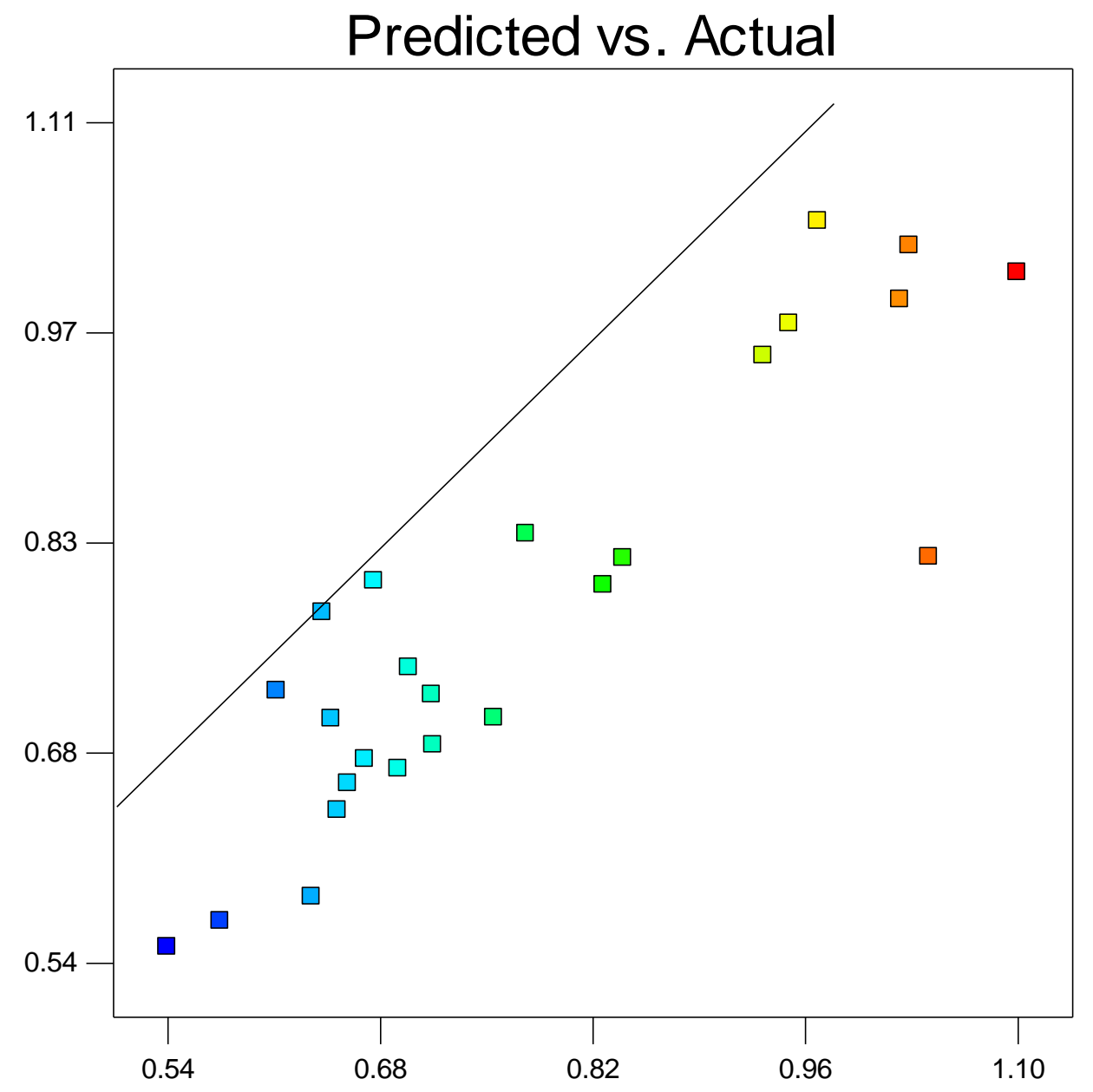

\section{$\mathrm{X}$ : Actual \\ Y: Predicted}

Fig. 6, Shows the effect of actual welding parameters on the welding pool width at the middle of the spacemen 'W2' response, against predicted. 


\section{Design-Expert ${ }^{\circledR}$ Software}

$$
\begin{aligned}
& \text { Fusion Area } \\
& \text { o Design Points } \\
& \prod^{3.641} \\
& 1.598
\end{aligned}
$$

$\mathrm{X} 1$ = A: Power

$\mathrm{X} 2=\mathrm{B}:$ Speed

Actual Factor

C: Focus $=-0.50$

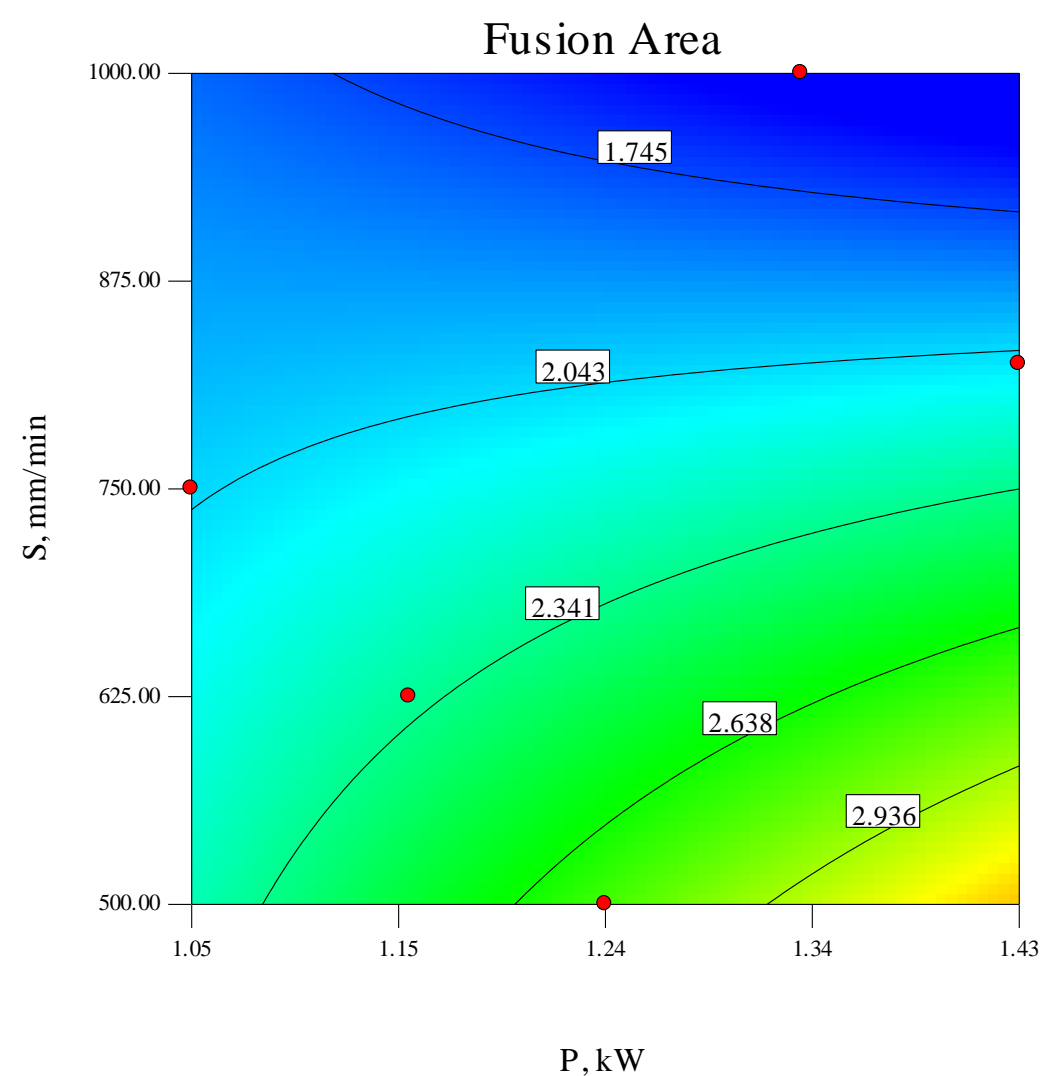

Fig. 7, Shows the contour graph of the effect of laser power ' $P$ ' and welding speed ' $S$ ' parameters on the welding pool area ' $A$ ' response, at focus value ' $F$ ' $=-0.5$. 


\section{Design-Expert® Software}

W 1

- Design Points

П.211

1.213

$\mathrm{X} 1$ = A: Power

$\mathrm{X} 2=\mathrm{C}$ : Focus

Actual Factor

B: Speed $=750.00$

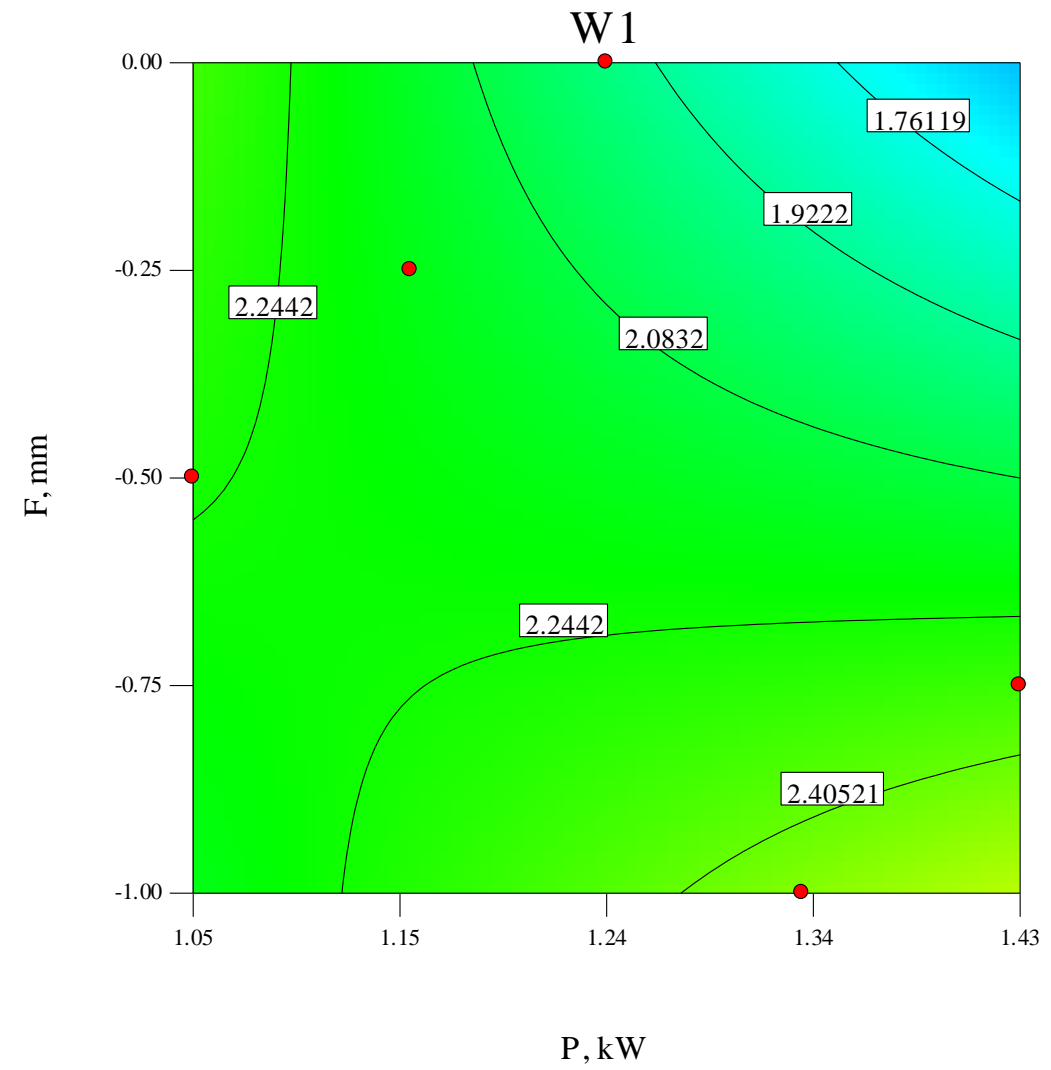

Fig. 8, Shows the contour graph of the effect of laser power ' $\mathrm{P}$ ' and focus position ' $\mathrm{F}$ ' parameters on the welding pool width at the serves of the spacenem' $\mathrm{W} 1$ 'response, at welding speed ' $\mathrm{S}$ ' $=750 \mathrm{~mm} / \mathrm{min}$. 
Design-Expert ${ }^{\circledR}$ Software

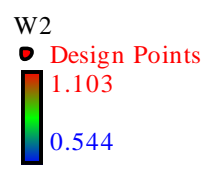

$\mathrm{X} 1$ = A: Power

$\mathrm{X} 2=\mathrm{B}$ : Speed

Actual Factor

C: Focus $=-0.50$

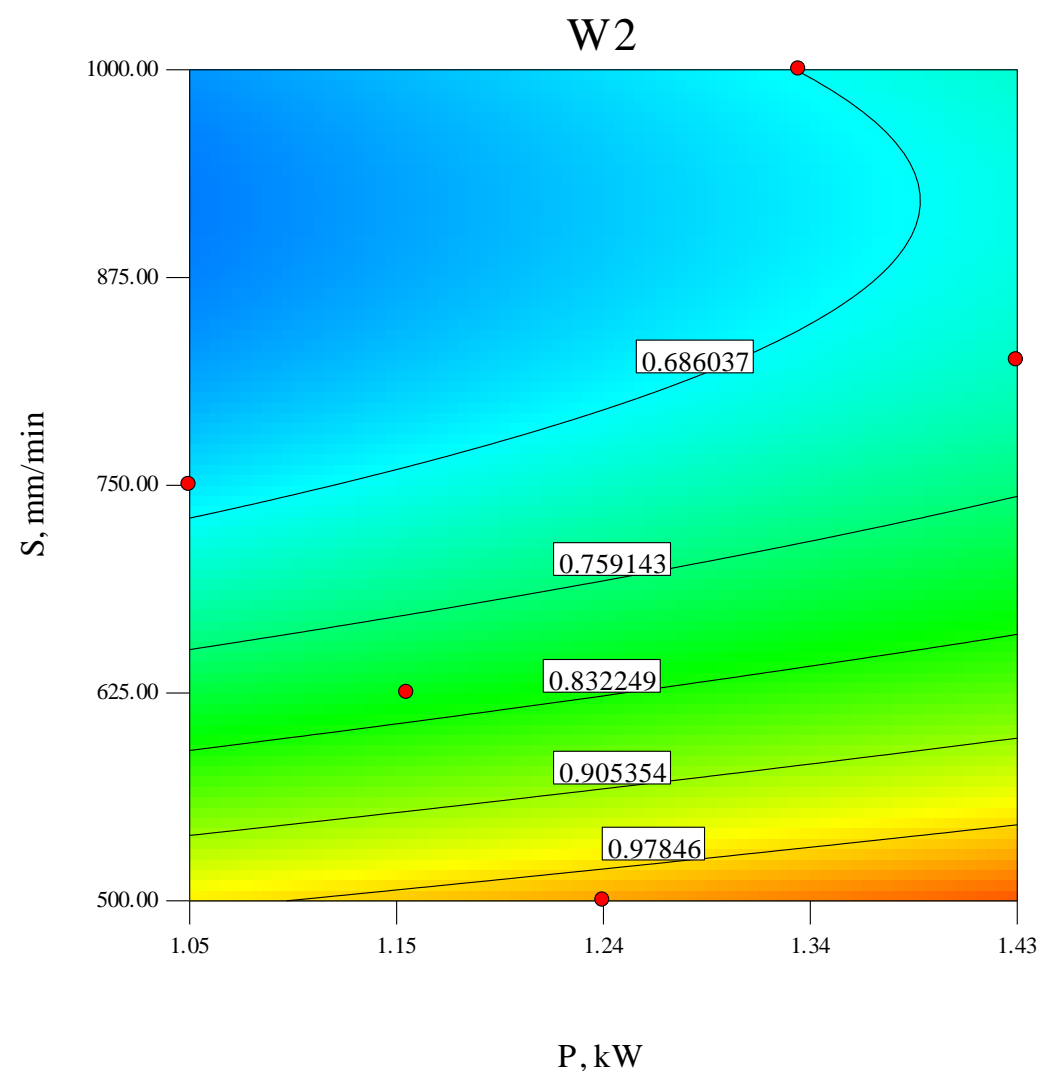

Fig. 9, Shows the contour graph of the effect of laser power ' $P$ ' and welding speed ' $S$ ' parameters on the welding pool width at the middle of the spacemen 'W2' response, at focus value ' $\mathrm{F}$ ' $=-0.5 \mathrm{~mm}$. 


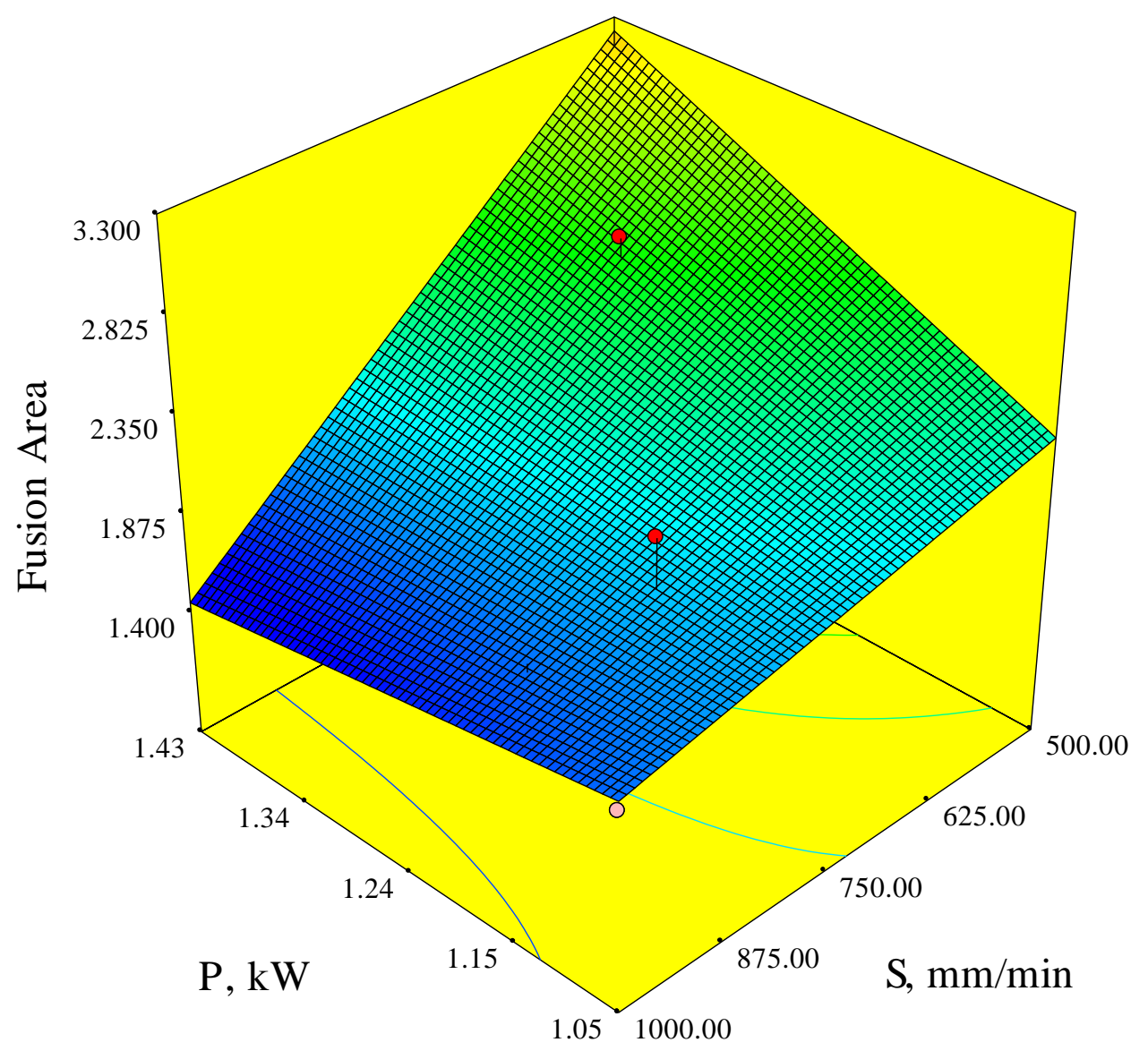

Fig. 10, Shows 3D graph of the effect of ' $P$ ' and ' $S$ ' on welding pool area 'A' response, at ' $\mathrm{F}$ ' $=-0.5 \mathrm{~mm}$. 


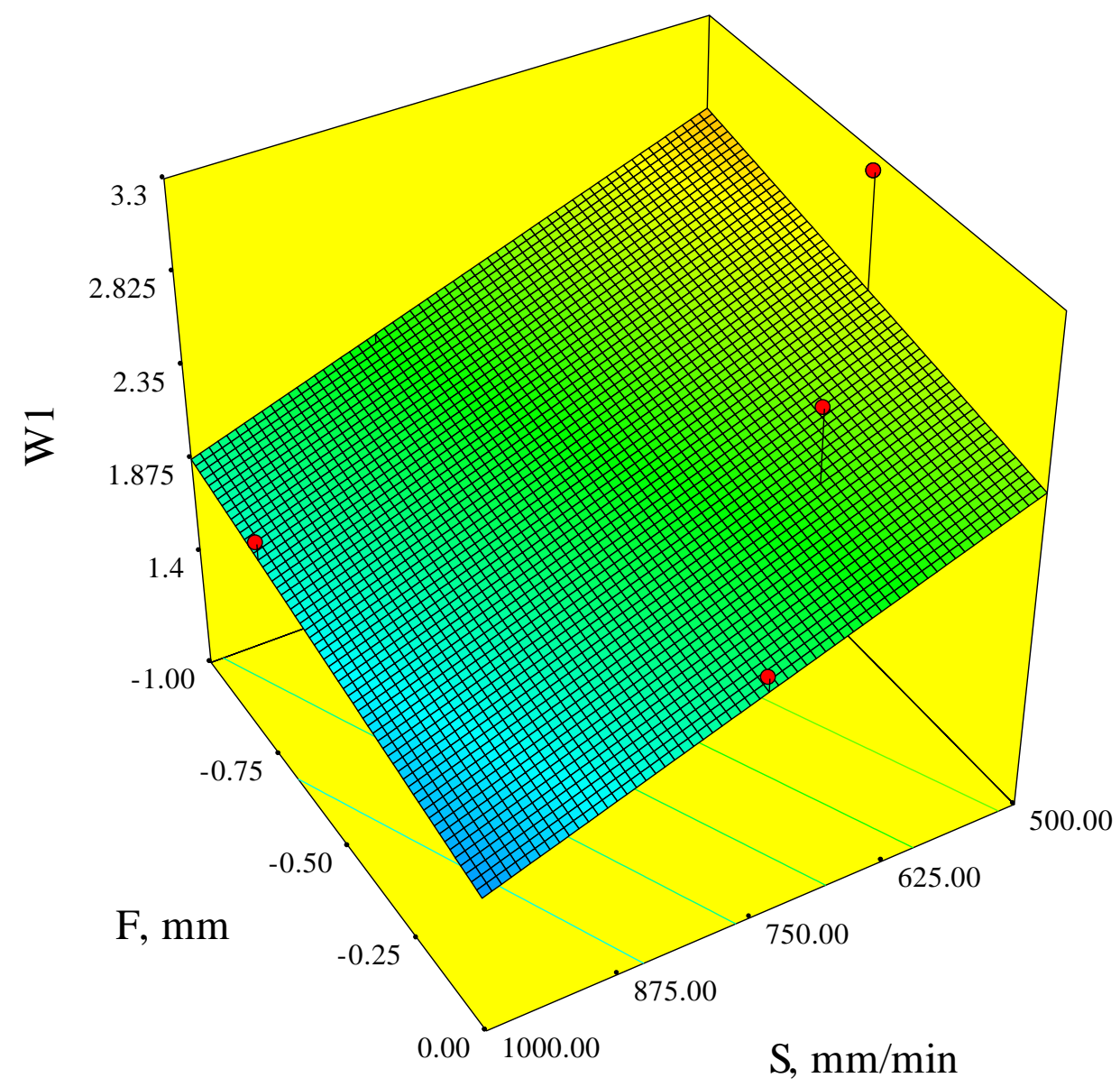

Fig. 11, Shows 3D graph of the effect of ' $\mathrm{S}$ ' and ' $\mathrm{F}$ ' on welding pool width at the surface 'W1' response, at ' $\mathrm{P}$ ' $=1.24 \mathrm{~kW}$. 


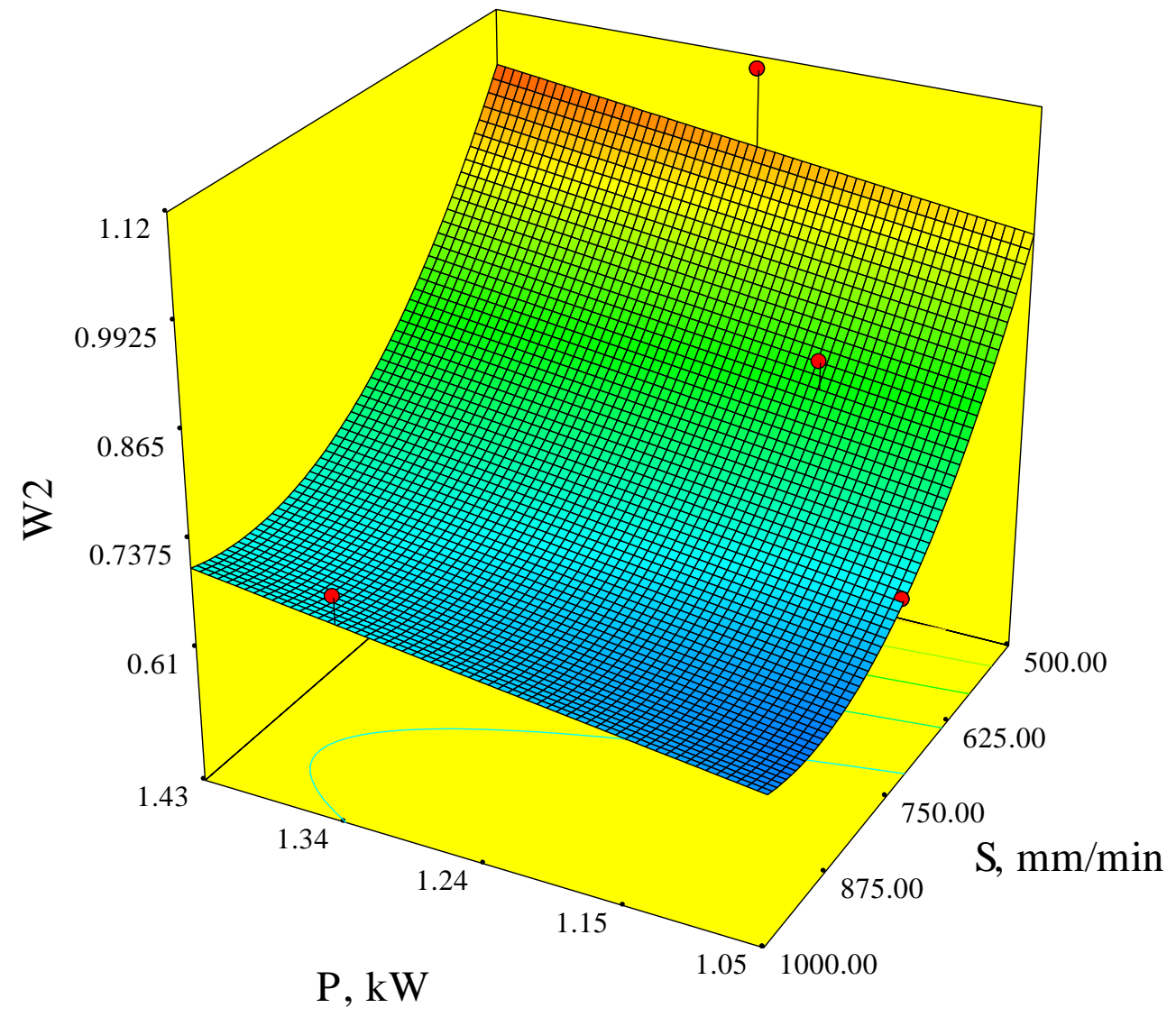

Fig. 12, Shows 3D graph of the effect of ' $\mathrm{P}$ ' and ' $\mathrm{S}$ ' on welding pool width at the middle of the spacemen ' $\mathrm{W} 2$ ' response, at ' $\mathrm{F}$ ' $=-0.5 \mathrm{~mm}$. 